\title{
The Crisis of Identity and the Quest for Development in Africa: The Place of Leadership in Creating a New Culture
}

\author{
Joseph N. Agbo* \\ DOI: http://dx.doi.org/10.4314/ujah.v12i2.10
}

\begin{abstract}
This work traces the part played by the leaders of societies, acting on the basis of certain philosophical justifications, to occasion the cultural crisis in Africa. It then shows how the activities of certain other leaders, using Japan and the U.S.A as cases in point, have worked to resolve the crisis of culture in their societies. It then argues that the African leaders are wasting a lot of time talking while their different societies are about to explode The paper sketches certain theories that already exist which the African leaders could appropriate in order to move their societies forward. It argues that just as science is a universal culture, our leaders should not wait for only solutions proffered by Africans before they can accept them. The paper argues that the prevalence of political and moral decay within African societies requires that new cultures be created by exemplary and purposeful leadership.
\end{abstract}

\section{Introduction}

Before we delve into this essay properly, we need to mention that ideology has become problematic concepts because of the crisis in the Marxist Movement ${ }^{1}$. Capitalism and Socialism became world-bifurcating ideologies and their polarization of the international community during the Cold War period made ideology an unpopular concept. Perhaps, the concept of "programmes of social change" would be a 
welcome replacement for the concept of "ideology" for all those who have been mentally traumatized by ideology.

At the political level, African leaders can test Kwasi Wiredu's non-party consensual democratic theory with few modifications. On the level of culture, there is nothing wrong with the cultural syncretistic interpretation of the existential situation in Africa. What is needed is a body of policies that would pronounce these needs as something to be pursued in the "national interest". W.E. Abraham, in his paper, "Crisis in African Culture" has called cultural syncretism, "an inescapable existential condition of modern viability"; pointing out that we need to espouse "a vital syncretist heritage of elements derived from diverse sources, able to constitute for the African a total resource for living, and offer to non-Africans a familiar feeling" (107). The welfarist economic arrangement that has made Sweden, Finland, Norway, and other Scandinavian countries, the envy of the world today can also be drawn by our leaders. Infact, Dr. Nnamdi Azikiwe, in his book, Ideology for Nigeria: Capitalism, Socialism or Welfarism, advocated a Neowelfarist approach to our economic planning so that capitalism, socialism and welfarism can co-exist. And the truth is that no economy in the world today is either fully socialist or fully capitalist. There is also the self-reliancist ideology championed by E.K. Ogundowole (Selfl-reliancism: Philosophy of a New Order) and others.

We have today a lot of theories, principles or ideologies which have come to us deliberately and by influence and by which the contemporary world has marched on. The most important thing is not that these theories should be advocated by Africans, rather it is that they be adaptable to the African situation. And as Olusegun Oladipo, in his article "Contemporary African Philosophy: Issues, Tasks, and Problems" pointed out, "it will be foolhardy for any culture to 
ignore whatever developments have taken place in other cultures in the name of cultural self-definition"(3). And so, "change which is deliberate and self-initiated, but which involve foreign substitutes" cannot hurt any culture and we see no reason for Africa to shy away from any necessary change and remain static because what is being appropriated is "foreign".

The foregoing argument, therefore, is enough pointer to those who think there is need to continue our seemingly endless intellectual discourse on Africa's cultural crisis. Of course, we are not advocating the stoppage of our theoretical research into issues that are of concern (and will continue to be) to all of us. In any case, that is not possible. However, what we are insisting on is that there are enough theories available in the world today which our leaders can draw from, and to remain in this sorry state while we wait for a "unique" African theory, from perhaps a larger-than-life African thinker, is to continue to prolong this shadow-boxing with phantoms which has characterized our struggle since independence. We shall say more on this in the concluding part of this essay and give reasons why it appears African thinkers are not doing enough.

\section{Development and Culture}

Let us make some remarks on the question of "development". This is because this concept appears to be a crucial issue in the consideration of culture. It has appeared on the scene as a kind of "god", it is the mantra that has become the center of our existential orbit and the central marker of our conscious thoughts. Unfortunately, the concept of "development" prevalent is predominantly materialistic. This emphasizes technology and industry as indices of higher culture and development. However, does it mean that when a society is an industrial giant, economically viable and technologically 
sophisticated, it is developed, and therefore, of a higher culture? Are computer hard and soft wares, electricity, five star hotels and skyscrapers, gigantic manufacturing firms, televisions, telephones and all other such paraphernalia of modernization and urbanization the most-important indices and proof of development? We are not asking these questions with disdain for the material well-being of the African society. Rather, we call for caution because it is this "material conception of development" that has led many an African thinker to wholly lift western thought systems and claim they are applicable to the African condition. Have we forgotten Albert Schweitzer's assertion (in, Civilization and Ethics) that "the prosperity of a society depends on the moral disposition of its members"? (76).

consideration of the critiques of the critics ${ }^{2}$ of western civilization, urbanization, and industrialization would make anyone to shudder. These critics paint a picture of a sick culture with pathologies of defeat and failure, of the degenerative conditions and processes in which all of us are subtly "compelled" to live.

It is interesting to know that in his monumental and popular work, How Europe Underdeveloped Africa, Walter Rodney began his discussion of the many-sided processes of development in human society from the level of the individual; which for him are "moral categories" which "implies increase skills and capacity, greater freedom, creativity, self-discipline, responsibility and material wellbeing"(1). Our interest here is that, Rodney had to list, skill, freedom, creativity, discipline, etc. before mentioning "material well-being". And for our present discussion, our interest is that certain individuals, political leaders, are crucial in determining the course of societal development. And although, Rodney observes that the individual's own level of development "is very much tied in with the state as a 
whole", we need must observe that the "society" is a creation of individuals, even if the former turns around to create the conditions under which that latter survives.

In a relatively recent (2009) paper, "Is The African Worldview Responsible for The African Predicament?" Obi Oguejiofor, having understood and explained a worldview as "nebulous, very changeable and is in its applicability, all a matter of more or less" (7) proceed to posit three major factors that are responsible for the sciento-technological under-developement of Africa. These are geography (the fact that climatic differences, especially in the long vertical line from Cape to Cairo, has very serious negative effect on the spread and exchange of inventions), biogeography (the fact that vast domesticable plants and animals become a disadvantage) and mystery (of slavery, colonialism and their result).

The more one reads Oguejiofor's paper and reflect on it and even more on his book, Philosophy and The Africa Predicament, the more the reality of the need for purposeful leadership becomes more and more necessary. There is absolutely no doubt that Africa needs a lift, not in one fellswoop, but exemplary leaders need to begin to emerge in the different states.

The question of whether societal development is based on an internalist (mind based, mentalist) theoretics or wholly on externalist considerations as remained a huge debate among scholars, especially philosophers. Although it is not the main focus of our discussion, it is important that we note that development cannot be discussed or understood without a thorough grasp of what the individual or society considers to be the nature of truth. In his essay, "Philosophy and Development: Metatheoretical and Methodological Considerations", J.C.A Agbakoba advances the concept of "progressive coherence", according to which we "gain truth 
in terms of coherence (consistency) that are more consistent than others... Truth considered as consistency ... is a si qua non development"(41). This idea of what Truth is, is ontologically mental, but existentially manifest. J.A. Aigbodioh's "The Mindset Factor in Economic Development" discusses the place of the individuals mindset, or what Anyiam Osigwe-Anyiam calls a "group mind", in the development of the society, and concludes that, "... real economic development does not depend on how theoretically valid or internationally accepted the models and strategies used are, but on the development and application of an appropriate mindset, as evidenced in the case of China"(31).

However, in his paper, "A Critical Examination of the Impacts of the Mind-based Theories for the Development of the Society", J.C. Chukwokolo, after considering the poverty and reductive limitations of both mind-based and materialist theses of development, concludes by averring that "development process shows in reality that internal and external factor influence it. The failure to appreciate this has led to the flaw of such theories"(103). What Chukwuokolo is saying is not that development is internal and external, but that it is, a la Hegel, internalist-externalist.

However, those who think that development is essentially mental and moral, support it with very serious understanding and interpretation of the idea of human nature, and according to J.I Omoregbe, in Knowing Philosophy, mental and moral development "must precede economic development through modern technology" (197), otherwise we would not have the material development that we all hanker after. Writing on the notion of material development as the result of the eventual resolution of Africa's cultural crisis, Oyeka Owomoyela, in his paper "Africa and the 
Imperative of Philosophy: A Skeptical Consideration", points out that:

To the extent that our philosophers are infatuated with applicatory science, they seem...to be unphilosophical about science and technology; they have not seriously considered the ramifications of such products and byproducts of science and technology as the neutron bomb, robotics and the marginalization of the working person, Kesterson, and love cannal, in order to determine whether or not science, in the final analysis, is a boom to mankind (210).

As noted earlier, we are not casting any aspersion on the need for material development in Africa, neither are we suggesting in any way that we do not need these comforts mentioned above. That would be taking the argument too far. Rather, we are saying that our adoption of any developmental or scientific attitude from outside Africa (or even within Africa) should be done with what Kwasi Wiredu calls "open utilitarian eyes" ("Problems of Africans Self-Definition in the Contemporary World", 61).

The word "development" itself is a multidimensional term. It covers economy, politics, religion, education, society, technology, information, environment, military and indeed all gamut of culture. However, on the level of daily consideration, development has become a heavily economic term. But philosophically speaking, "development" can either be positive (in which case it is synonymous with "progress", "upwardness", "advancement", "improvement", "growth", etc) or negative (in which case, it is called "underdevelopment", "regress", etc). 
But the development process can also get stuck in the middle of somewhere. And at that point, development is said to be stagnant. For lack of a better term, this situation can be called "undevelopment" or "nodevelopment".

In as much as all these dimensions are important areas of concern for any philosophical analysis, we want to say that it is the positive sense of development that stimulates our research in this paper. It is within this context that those in the third world countries reject the "under-developed" tag by western analysts, preferring instead to be called "developing" Countries. It is the equation of "development" with civilization, urbanization and modernization (whatever these terms may mean) that has enabled the western world to regard Africa, many parts of Asia and the third world as "underdeveloped". But according to Kwasi Wiredu: in, Philosophy and an African Culture.

The Western World is "developed" but only relatively. Technological sophistication is only an aspect and ...not the core of development. The conquest of the ...moral ...by the spirit of rational enquiry remains... a thing of the future even in the West. From this point of view, the West may be said to be still underdeveloped. The quest for development then should be viewed as a continuing world historical process in which all peoples... are engaged (105).

Indeed, there is a sense in which whatever development goes on in society is a cultural one. That is to say, it must affect facets of its culture for any development to be concrete and significant. The late Professor Campbell Shittu Momoh, in his paper, "On Cultural philosophy" 
averred that development would indeed amount to nothing if it is not the development of culture (1-15).

Conceived as change, development immediately impacts on culture. For it is a manifestation of mature development for any culture to create an in-built mechanism that prevents, rejects or reverses unwanted or unwarranted change. Cultural change or development depends a great deal on epochal or historical needs. And without succumbing to the bogus claims of historicism, we want to say that these historical needs are dictated by the experiences of men, the men that make history by creating a somewhat higher dimension of culture.

This is, perhaps, why Momoh makes a distinction between culture and experience; describing the former as a "totality" of the latter, and insisting that the latter is a "moment" of the former. Accordingly, he states in, Philosophy of a New Past and an Old Future, that:

For the moment, culture is static and passive whilst experience is dynamic and active. Experience is culture at work on a daily basis and culture is experience distilled, crystallized and synthesized over time (4).

Our concern is not really to define culture, for it is a compendious term. According to B.W. Andah, in, African Development in Cultural Perspective, "culture embraces all of the material and non-material expressions of people as well as the processes with which these expressions are communicated" (62).

Our concern is, therefore, that once this communication becomes vague, difficult or impossible, a crisis of culture occurs, whether we realize it or not. This crisis can permeate 
the three components of culture as classified by Ely Chinoy, in, Society: An Introduction to Sociology. These components are institutions, ideas and material products (28). Any crisis of identity, we contend, is a cultural (which can exhibit itself in economy, politics, norms, and even manner of dressing or speaking), and a cultural crisis is the quickest, automatic grounder of every and any attempt at development. That is why Kluckhohn and Kelly sees culture as "a historically derived system of explicit and implicit designs for living, which tends to be shared by all..."16 It is precisely because culture is "historically derived" that we insist that men, the leaders of men, the makers of history, should arise in Africa to effect changes that would directly impact our culture and consequently impart on the society at large.

\section{Perpetrating Cultural Crisis through Leadership}

Our claim is that leadership is the crucial factor in the evolution of cultural crisis in Africa. However, the truth is that the attempts were based on certain philosophical assumptions by some racist and imperialist-minded philosophers and other writers who wrote in the $18^{\text {th }}$ and $19^{\text {th }}$ centuries. We are aware of the degrading comments on blacks by such lofty philosophers and writers as David Hume,Europe celebrated anthropologist Lucien Levy-Bruhl, Immanuel Kant and above all G.W.F. Hegel. Professor I.C. Onyewuenyi, in his book, The African Origin Of Greek Philosophy, has pointed out the contributions of King George II of England, and Elector of Hanover, Germany to the establishment, in 1774, of the University of Getteingin in order to support false and degrading remarks about the contributions of ancient Egypt to world culture and civilization (chapter 3). We can see that leadership contributes to the fashioning of a thought culture and later, it 
will be the same leadership that would put the content of these thoughts into concrete existential situations.

The infamous Berlin Conference of 1884-5 was where the destiny of Africa was "sealed, stamped and delivered". Colonization was conceived there as a paternalistic mission, a civilizing adventure which was meant to make the African, hitherto conceived as a primate, a "civilized" human being. No wonder why Hugh Trevor Roper (as quoted in Ali Mazrui, "Political Nostalgia") remarked that the only history which Africa has is the history of Europeans in her territory, noting that "the rest is darkness and darkness is not a subject of history."(6) Slavery may not have directly affected our culture in Africa although it affected the culture of those Blacks in Diaspora. But colonization was a dehumanizing experience, and infact, a complete affront. Professor Basil Davidson, in African Civilization Revisited, pointed out that the debunking of this so-called supremacy of whites over blacks or the inferiority of blacks over whites is "the beginning of historiographical wisdom" (26)

However, the general consensus seems to be that without the distortions imposed by colonial hegemonies, the African peoples would have evolved unique, primordial and adaptable socio-cultural and political systems which could have purely emerged from African orientation, predicated solely on African metaphysics, African world views, and ontologies or ontological foundations. The "colonial factor" is so pervading that 'Segun Oladipo regards it as "the critical factor in the generation of the crisis of identity in contemporary African life" ("Contemporary African Philosophy...")

The intent of this section is not to chronicle all the usual hypotheses and theories put forward, for or against colonialism in Africa; rather, it is to argue that if there were 
no western leaders (of industries and of states) that decided to "Scramble for Africa", and if there were no "leaders" (in their own right) that agreed to come down to Africa as Missionaries, High Commissioners and Governor-Generals, there may have been no colonialism, and consequently, there just may have been no African cultural crisis. Basil Davidson, in his book Africa in History, quotes Sir Charles Elliot, $1^{\text {st }}$ High Commissioner of the Protectorate of Kenya, to have once said: "We have in East Africa, the rare opportunity of dealing with a 'tabula rasa' ...an almost untouched and scarcely inhabited country where we can do as we like"(122). This is the kind of "mind-set" that can create a crisis of different dimension anywhere in the world!

We are not embarking on the phenomenon of "leadership bashing", but it is the case that if the colonial leaders began Africa's cultural crisis, the post-independent leaders compounded it. The Blackman simply took over from the Whiteman after Independence, using still the same colonial "utensils". De-colonization should not have been regarded as an end itself: that is, as an end to Africans' search for identity.

Leopold Senghor, being the former President of Senegal, must have approached his leadership (or is it rulership?) with the cultural traditionalism in his philosophy, which Kwasi Wiredu, in his paper "Conceptual Decolonization in African Philosophy" has dubbed, "the romantic negritude of Senghor's suppositious Socialism”(12). The spate of political nostalgia that runs through Africa today has been described as a failure of past, especially postindependent, leaders. Ali Mazrui ("Political Nostalgia") has said that this kind of political nostalgia and amnesia leads to a "groping of cultural roots" and the kind of "Romantic primitivism" of Senghor. 
Apart from the cultural traditionalism which the leaders of post independence Africa embraced, one can also notice that African leaders of the 80 s and 90 s seem to have been following the philosophy which Oladipo calls "cultural surrender". This philosophy bothers little about identity, rather it considers the question of how Africa can achieve monumental scientific development as the basic need in Africa today. Oyeka Owomoyela quotes Paulin Hountondji as saying that, the Camerounian philosopher, Macien Towa, is a classic example of these group of philosophers, says that "we should try to discover, not our unrecognized greatness or nobility, but the secret of our defeat by the West:" (162). And the implication of this for our present discourse is that in the running of State affairs in Africa today, we are busy Europeanizing and/or Americanizing our culture (understood in its broad sense) all in a bid to discover this "secret of our defeat by the West". Massive and uncritical importation of goods and ideas from the West became the order of the day, especially since they bring sponsorship.

We have, in the preceding paragraphs, sketched out the way we have got (directly or indirectly) into cultural crisis through political leaders. The missionary leaders also came to Africa and debased our traditional religions and our educational system, introducing foreign languages for education purposes, creating a cultural crisis that is very evident. We now proceed to consider the USA and Japan as examples of places where political leadership have been instrumental in creating new cultural identities.

\section{Instances of the Growth of Culture through Purposeful Leadership}

Usually when we talk in "conscious", "critical", "reflective", "reconstructive", and other such mental terms, we tend to give the erroneous impression that the whole gamut of our 
daily lives really involves the kind of logico-critical rigour that we have in mind. But it is nearer the truth to say that many of us, many times, carry on with living without the kind of conscious reflection which we exhibit in many a philosophical discourse, discussion, article, or book. As a result of this state of affairs in normal life, leaders are usually saddled with the responsibility of articulating the "heart beat" of the citizenry; that is, to "think and act for them. There in a sense in which one can argue that any leader worth the term must be someone who can follow abstractions. This position is, off course, platonic. Usually, the "followers" never see what the leaders see. Many of us don't want to lead. We are content with following, and what bad followers we have been!

Men and women like de Gaulle, Churchill, Golda Meir, Joan of Arc, Napoleon, Lincoln, Stalin, Mao Tse-Tung, Nkurumah, Castro, etc have made so much an impact that their actions have influenced, not just their individual States/Societies, but the entire world.

The "Japanese Miracle" is often cited as a good example of a people that have realized the goals of freedom and progressive development without compromising their cultural identity. Till today, analysts still search for an exhaustive and a comprehensive explanation of how a people that suffered the atomic bomb blasts of August, 1945, and all the accompanying devastating effects, could practically "rise from the dead" 3 decades later. Professor Youichi Ito has pointed out that when a people could no longer relate what they are doing or what they now do with what they were doing or with what they were, they are then caught up in a crisis of identity.

However, the Japanese miracle is no miracle in the sense in which we understand that term. Japan's rise was a deliberate and conscious attempt by the leaders to rebuild the 
citizen's low psyche after World War II, and create a new culture from the bowels of an ancient social order and the sprouting bud of a new, though hazy, reality. Professor Youichi Ito, in, "Cultural Identity: An East Asian Perspective", traces the genesis of the identity crisis in Japan as well as the resolution, and how that resolution can be explained. For him:

This sense of continuity was shattered by defeat in World War Two. The Japanese lost confidence and suffered from identity crisis and inferiority complex. This state continued until the middle of the 1960s when the Japanese economy reached the level of advanced industrialized countries. At the end of the 1960s, a new search for identity began... and many books and articles were written on this subject. It was a very long and thorough period of intellectual activity... one of the functions of this intellectual boom was to relate Japan's industrial and technological success to its traditional cultural legacies. Today, Japan's industrial and technological success is explained in Japan by Confucian work ethics, with the emphasis on group harmony and consensus, inter-group (rather than inter-individual) competition (143).

The above lines reveal that Japan's search for cultural identity began after she achieved industrial greatness. There is nothing that says Africa should (or should not) go the same way. Although, Japan was practically compared to go this way as a result of the holocaust. The average Japanese was 
faced with the existential challenged of survival before thinking of identity.

We believe that with the level of intellectual "philosophical" re-examination that has gone on in Africa since the 1970s (at the dawn of African Philosophy), the Africans have been able to theoretically rediscover who they were. They have also been able to discover WHO they are in this contemporary world as well as HOW it is that they came to become who they are now. What remains is for African leaders to transform many of these intellectual facts into practical tasks. For there is nothing that says that ideas or theories that would work in Africa must be uniquely African in terms of orientation or the theorizer. This is why Professor Sophie Oluwole (in The Africanness of aPhilosophy) disagrees with Professor Paulin Hountondji on the latter's insistence on geography as a determining factor for the Africanness of a philosophy. For Professor Oluwole;

It is only because some literary pieces partake in the general goal of African literary experience that we are justified to classify them as "African", not just because an author is African in origin. This is why we cannot rule against the possibility of an alien writing an authentic African philosophy just in the way many of what some of us produce are nothing but Western philosophy (216).

As noted earlier in the introductory part of this essay, there is an embarrassment of ideas/theories, both by Africans and non-Africans, that exist in the contemporary world which our leaders can adapt or appropriate in order to "bounce us out of inferiority complex forever". And we shall undertake in the last session of this essay, to highlight some of them. 
The Japanese economic achievements as well as her cultural re-awakening were brought about by sheer leadership policies, through cultural adaptation. Professor Kwasi Wiredu ("Problems in Africa's Self-definition...") notes that in Japan;

Modernization has... come, not by sheer force of events, but through a deliberate national policy. It was through a deliberate and systematic policy that the Meiji rulers of Japan in the second half of the $19^{\text {th }}$ century worked to abolish Japanese Feudalism while retaining (even by law) their traditional value (161).

The Japanese leaders were able to exploit the opening provided by global communication in the media. In a world in which information has become more fundamental than matter and energy, in a world where technological giants are manipulating and influencing others through the media, Japan asserted her world-wide relevance and has sustained it ever since then.

writing on "The Status of Principles in Confucian Ethics", A.S. Cua is of the opinion that it would be difficult (if not altogether impossible) for an observer to

understand practical reason in Confucian ethics without appreciating the internal point of view of those operative standards of argumentative competence and the guidelines provided by language and culture. Or more generally, it is plausible to maintain that there is a "social practice of reason" that comprises such activities as deliberating, explaining, justifying, reasoning and choosing. Associated with this practice is a 
set of general guidelines provided by tradition and culture. The aim of these activities and guidelines is to enable the members of the community "to achieve better solutions to their problems than would be possible without the help of these publicly available guidelines (241)

The culture and traditions of Japan have remained preserved inspite of acceptance of influences from other cultures, especially Eastern Europe and the Americas. With what military action had done to her, following on the heels of Empoeror Hiro Hito's global expansionist ambition, Japan had to forget all about the military and concentrated on technological development. The focus to rebuild Japan was so intense that an average Japanese worker would be "begged" to take leave from work and he/she would reject the offer!

Today a country like the United States of America (USA), that is an amalgam of cultures, can stand strong all because of the foundation laid by her founding fathers, and maintained and improved upon by leader after leader. On July 4, 1776, a group of men that loved America (perhaps, more than their own lives) gathered together in Philadelphia and read (by Thomas Jefferson) what was to become "the American Declaration of Independence". Those men, at that Continental Congress Meeting of that momentous day, took a road that the United States has continued to follow for over two centuries: the Culture of Liberty and Equality. And over two hundred years later, in 1984, President Ronald Reagan of the USA (in an address before the $39^{\text {th }}$ session of the U.N. General Assembly, New York) was to say: "I want you to know that the Government of the United States will continue to view this concern for human rights as the moral centre of 
our foreign policy. We can never look at anyone's freedom as a bargaining chip in world politics"

In a country like the United States, where you can hardly find anyone who is an "American-American" (it is either you are an African-American, German-American, Chinese-American, Jewish-American, Japanese-American, British-American, or something of that sort), there is a high degree of cultural growth despite the fact that they fought a disastrous civil war. Fortunately, it was the resilience and tenacity of Abraham Lincoln that saw them through those civil war years, just like the "immortal" words of Winston Churchill, during the $2^{\text {nd }}$ World War, still ring in the ears of Britons up till this day.

In the U.S.A., no matter which Party or which person is in power as the President, there is a certain "national culture" that must be up-held. And no matter how philosophically difficult it is to definitely and comprehensively define this underlying culture, it is true that Liberty and Equality or Democracy are its best approximates. This culture creates order (for "order" is not just a legal creation; otherwise, military regimes with their flood of decrees would have no crisis of legitimacy), it is also a means of integration for the multi-farious peoples in the U.S. society. In addition to all these, national culture also makes events in each society intelligible and significant, and also controls changes by making such changes gradual and qualitative. That is why no mad General, no matter how irked he is about events in the U.S., can wake up one inglorious morning and role military tanks into the White House, with the intent of overthrowing the democratically elected President of the United States of America. That would be almost unimaginable! 
And 25 years after Reagan, Barack Obama, after being sworn-in as the $44^{\text {th }}$ President of the United States of America on January 20, 2009 was to say in his inaugural address:

Let us mark this day with remembrance, of who we are and how far we have traveled. In the year of America's birth, in the coldest of months, a small band of patriots huddled by dying campfires on the shores of an icy river. The capital was abounded. The enemy was advancing. The snow was stained with blood. At a moment when the outcome of our revolution was almost in doubt, the father of our nation ordered that these words be read to the people: "Let it be told the future world ... that in the dept of winter, when nothing but hope and virtue could survive... that the city and the country, alarmed at one common danger, came forth to meet (it)".

America, in the face of our common dangers, in this winter of our hardship, let us remember these timeless words. With hope and virtue, let us brave once more the icy currents, and endure what storms may come. Let it be said by our children's children that when we were tested we refused to let this journey end, that we did not turn back nor did we falter; and with eyes fixed on the horizon and God's grace upon us, we carried forth that great gift of freedom and delivered it safely to future generations.

Now, as we write Obama is pulling the U.S. troops out of Iraq and closing down Guantanamo Bay in Cuba, inspite of 
resistance from diehard Americans who wanted to continue with business-as-usual. This is leadership!

\section{Culture, Leadership and Contemporary Africa}

When in the opening lines of his small but insightful book, The Trouble With Nigeria, Chinua Achebe wrote that, "the trouble with Nigeria is simply and squarely the problem of leadership"(1), he cannot be interpreted as having been unaware of the role which culture plays in societal cohesion. Rather, it can be deduced that he saw political leadership as crucial and central to the creation of other institutions where culture would thrive or manifest. Whatever amount of philosophizing or theorizing that is done can become real or unreal ONLY after it has been tested on the ground by political leaders. That is why some of us have maintained that "philosophy" is philosophy because it is significant and relevant as "political philosophy"; and we do not mind being branded "parochial", "myopic", "reductive" or whatever.

It took a Harry Truman to politically order the dropping of the atomic bombs, code-named Little Boy and Fat Man, on the Japanese cities of Hiroshima and Negasaki. But for that singular political decision, the philosophicoscientific excorgitations of Heisenberg, Sakarov, and Einstein might just have remained another "laboratory mystery". It took a Lenin to tryout Marxism, a Mussolini to test out Machiavellianism, as well as a Cronwell to put Locke and Rousseau into concrete, real-life situations. And in all these political attempts, cultures have been created, some of which have been phased out and some of which are still with us in the world today. Culture is dynamic, and like history, it is the activities of men that create and give meaning to it. In these "activities" of men, there are some men, the leaders, who are the fillip and catalyst that propel this cultural dynamics. 
And indeed, if there is any country where sheer political leadership (or is it un-leadership) has been a major problematique, it is Nigeria. Achebe's thesis was justified by General Abdulsalami Abubakar, who took over power after the demise of General Sani Abacha. In just 4 months of Abubakar's regime, the citizens of Nigeria witnessed the kind of mental and physical relief which they never had in 13 years. And although an enduring national culture cannot be created in a few months, no one, even the greatest critics of the garrison political theory, would deny Abubakar's geruine and yawning desire to give Nigeria a new lease of life. And that he did when he completed a transition to a civilian government. Nothing else was responsible for that current lease of life in Nigeria but the exemplary and purposeful leadership of Abubakar himself.

When Umaru Musa Yar'Adua became Nigeria's President on $1^{\text {st }}$ October, 2007, Nigerians began to notice something (after only few months) that they didn't have in the 8 years of Olusegun Obasanjo - the respect for the rule of law. Because Yar'Adua insisted that all Court Orders must be obeyed to the letter, we find out that other persons holding executive or appointive positions (Governors, Ministers, etc) followed suit in obeying Court Orders. A culture of obedience to the rule of law was brought about simply because, from the top (The Presidency), that culture has been planted. Other parties, apart from the ruling People's Democratic Party (PDP) are wining election cases at the Court of Appeal. For example, under the Obasanjo Presidency, it would have been highly improbable to think of the former labour leader, Comrade Adams Oshomhole of the Labour Party, wining the election petition to become the Governor of Edo State, mid-western Nigeria!

In 1985, when a phenomenon named Mikhail Gorbachev emerged at the kremlin as President of the 
Supreme Soviet, little did the world realize that that occurrence was a sociopolitical hurricane that would later sweep across the globe, pulling down age long walls (both physical and ideological) and redefining the boundaries of international relations. Gorbachev's Perestroika ${ }^{3}$ was a realization that the then Soviet Union could not continue to be, in Churchill's famous characterization, "a riddle, rapped up in an enigma, behind an iron curtain". And indeed, as at the time Gorbachev came, it had become both socially and logically impossible to continue to hide (through some smart semantic statements) the crisis that was threatening to blow up the then Soviet Union. When the role call will be made of the great leaders of the $20^{\text {th }}$ century, Gorbachev's name would rank among the topmost of them.

To say that in Africa today, we do not have an avalanche of ideas that our leaders can draw from, is to continue to play dice with our destiny. If we agree with Professor Anthony Appiah in his book, In My Father's House... ", "every human identity is constructed"(174), then we know that this "construction" is done by leaders, men and women, who would have to exercise political power to determine what is relevant and what is not. As T. U. Nwala in Igbo Philosophy, rightly pointed out: "political power does not operate in the abstract... the human being who exercises this power determines what is relevant and what is not, and therefore, determines the character of the state"(164). "Character" here deals with the things which society considers as Truth and Values, and so deals directly with the essential part of its culture. Supporting the view that our African leaders cannot continue in this way and that whatever philosophizing we do is only to add to the ones that already exist, W.E. Abraham ("Crisis in African Cultures"), wrote that: 
In this post-colonial era, when the power and authority of decision-making lie with Africans themselves, there exists an embarrassment of riches in the shape of theories and methods upon which political and social decision-makers can draw (159).

We pointed out earlier that some of these theories and hypotheses are by Africans themselves while some are from foreign thinkers but the important thing is that they should suit the African condition. If we encourage cross-cultural studies, we should also realize that it involves cross-cultural borrowings and indeed, whether or not we encourage the latter (borrowing), it is bound to occur by the sheer strength of cultural dynamics and social interaction.

In a world interlinked by globalization, we cannot continue to ignore what is happening in other cultures and it doesn't matter whether we accept or reject them. These things stick around us like our skin. In an earlier paper ("Africa Within the Globe... "), it has been observed that globalization pose both philosophical and intellectual challenges to the African and that since there is something universal (Kantian) about the proposition expressed by the concept, seeing it only in economic terms would deny Africa the chance to give it a "human face" and then consequently, the continent would not have the opportunity to put it into constructive engagement and appreciation. The paper argues that:

Globalization is a practical grasp of "something" that has its roots in philosophy. The so-called "proponents" of globalization appear to be following an inevitable course in the philosophy of history. That is why it becomes really 
difficult or uncharitable to blame or praise anybody for its evils and gains, respectively (183).

Earlier, we pointed out that one of the theories that we have now is the one by Kwasi Wiredu: non-party consensual democracy ${ }^{4}$. Wiredu, like J.S. Mill centuries before him, points out the danger of majoritarian democracy, noting that it does not, anywhere it is practiced, really manifest the true nature and value of the "democratic ideal". But by far the greatest advantage of the non-party consensual democracy is the fact that there is something indigenous about it. For our traditional pristine kingship political system was based on consensus and of course, the kind of political parties that exist in the contemporary world were not in existence in traditional Africa. That is why Wiredu sees the kind of government formed in a possible non-party arrangement as "a coalition, not, as in the common acceptation of parties, but of citizens" (Nwala: 61). This way, minority agitations that have caused wars and clashes from Rwanda and Burundi to Liberia and Somalia and South Africa and Nigeria; infact, all over Africa, would be considerably checked. As T.U Nwala wrote, concerning the Igbo traditional political system; "democracy, whether primary or representative, was the bullwalk of the whole political system. UNANIMITY and all the rigorous processes and compromises (igba-izu - period of consultation) that led to it are all efforts made to contain the wishes of the majority as well as the minority" (168). It, therefore, means that if there is something in this non-party consensual democracy that embodies our identity as a people, we should embrace it with modifications to enable us solve some of the ethnic problems in Africa. In Nigeria this system was practiced as "Zero-party election", during the local 
government polls, in the ill-fated Babangida and Abacha transition agenda, although it was still based on majority decision. However, we can still keep fashioning it until we achieve some degree of adaptability, the enormous size of most modern states, notwithstanding.

We alluded earlier to cultural syncretism as a correct interpretation of the cultural situation in Africa, and with the ideology of self-reliancism, we can then address the issue from "the top". The snag is that some thinkers think that the African has not discovered his "self". However, we think that this may not be totally true. It is only true to the extent that the individual African has refused to acknowledge the fact that he should attempt a change in his orientation. But at the theoretical level, at the level of the thinker, it has been recognized that the African "self" exists in a "cultural syncretist" atmosphere and if that self does not want to suffer further ontological derailment, it should see this as its existential situation, and then fashion there from epistemic bases for the purpose of developing the society.

On economic theory, we have a system that incorporates a capitalist orientation as well as a socialist one, and with a welfarist policy, especially in a country as diverse as Nigeria, all the ethnic groups can be sure of a sizeable chunk of the "national cake". Infact, what is really wrong is not the economic system which African countries operate. Rather, it is the fact of embezzlement by the political rulers, and this is where we have to develop a certain kind of culture: the culture of Morality and Resistance to this continued siphoning of Africa's wealth. The fact of corruption is the single most-important impediment to the all-round development of the continent of Africa. That is why the qualities of leadership - Health, Intelligence, Social sensitivity, Competence, Active participation, Eloquence, Love, and Self-control - listed by Nwabuiro Ideyi in his 
article, "Leadership and Nigeria's Quest for Good Governance: A Critical Evaluation" (164-176), would amount to nothing if the kleptomanic tendencies of African rulers are not put in check.

\title{
Momoh's Moralism
}

In the "Philosophy of a New Past and An Old Future", C.S. Momoh calls the twin phenomenon of bribery and corruption as "unofficial ideology, our lingua franca, the universal language which is spoken or understood in every nook and cranny of Nigeria" (115). And although one cannot wholly agree with the entirety of Momoh's varied and almost comprehensive musings on corruption, our interest in his ideas is on his panacea to clean "the Augean stables of corruption".

Some of the weird things that he says on corruption include: that the national malady "should be allowed to permeate and pervade the whole gamut and spectrum of society ... it is not moral but it is at least fair and just" (104), (another way of saying that corruption should be legalized so that each act of it would cancel another act), that nature is the first cause of corruption, that poverty is not exactly the cause of corruption (120), that nepotism and acts done on tribal grounds are not corrupt acts, etc. He is, however, able to hold on to these positions because he defines a corrupt act as:

\begin{abstract}
Any immoral but non-violent action on the part of the stronger party to accept, or on the part of the weaker party to give, extra-official gratification, in cash or kind, in order to do or induce wrong or right actions (115).
\end{abstract}

But if I deny someone his due, does it mean that it is not a corrupt act? What about someone who gives something to 
others, not for "favour", as it were, but to get what is "rightly" his privilege? Is that not a corrupt act?

Momoh argues, and rightly too, that capitalism and socialism, because they are ideologies of the system, cannot fight corruption. For him, "capitalism, as a western economic ideology, cannot by definition, be bothered with corruption. And this is strictly because immorality is the very prop of its theories - slave trade, colonization, apartheid, racism, oppression, etc"

$\mathrm{He}$, therefore, advocates Moralism as the ideology of ideology, as a basis to fight corruption. For him,

Moralism is a doctrine that puts the other before or alongside the self. It holds that honesty, service and concern for the interest of the other ought to be the basis and measure for all actions and polices... Moralism is a doctrine which applies in the system, in offices, in factories and in homes (127).

Moralism is based on morality, it is a philosophy in action and so can be enforced. And who knows, it is perhaps, the panacea for corruption because one of its enforcing tenets says that "active oath taking" should be administered on our public office holders "in the name of indigenous Gods or spirits or Juju" (132). And according to Momoh, it would result in the public office holder being conscious of the invincible mystical force watching over him, for the public office holder would fear his native God more than the other wise merciful Judeo-Christian god or Islam's Allah. Secondly, the active oath taking would engender faith in the system.

However, one of the problems is that as a result of the hierarchical structure of the gods, the person who has taken 
an oath with one god can always take refuge in some "bad" and "dubious" gods to escape punishment at least temporally, as is often the case.

But a theory based on altruistic consideration of the other before or long side oneself would definitely alleviate the phenomenon of corruption greatly. And when this is added to a culture of "social thinking", it would go a long way to eliminate corruption. For by then, the human being who holds political power would understand the purpose, use and operations of authority. Many societies in Africa are not really poor. If only their resources can be equitably distributed, they would not require the so-called aid from the World Bank, I.M.F, etc aid that have far-reaching devastating effects than the dreaded AIDS!

As J.I. Omoregbe in his book, Knowing Philosophy has rhetorically asked: "how can there be development in a country in which public funds are embezzled by those who control them and who are supposed to use them for developmental projects? How can there be development in a country in which self-interest is the dominant rule of action?" (197). This culture of Resistance and Morality can only be developed through mass-education by thinkers in Africa. This way people would begin to realize that society cannot last for long with a fake or forced identity. So, we discover that what we have been saying about the central role of leadership does not in any way negate or render insignificant, the fact that there should be a search for continued higher degree or culture by not just Africa's philosophers but thinkers in other areas like, anthropology, history, politics, religion, sociology, language, etc. But to achieve the goals of development, our leaders already have enough theories that can form the pedestal that can be used to ideologically articulate our needs and propel our way forward. 


\section{Concluding Remarks}

As a concluding preamble, let us note that any kind of "Alleluia" intellectualism (praise singing of leaders in Africa and praise for ideas from the West) would not help the African course for development in any way. Our thinkers should not just develop a culture of social thinking but equally that of committed research. However, it is unfair to say that contemporary African thinkers have been idle or have not done enough ("enough", not in the sense of saying "we have got all we want, let's stop"). Part of the reason it seems the thinkers are not doing enough is because the African societies are without reading or literary culture, without good communication facilities and network. So most times, they do not know what is happening outside their base(s). Another reason is that in societies without adequate publishing capacities, the number of books that get published is not commensurate with the actual number that is ready for publication. But by far the greatest, self-created problem of the African thinker is that she/he is caught in a web of negative comparison. For many of us, we must produce a Locke, a Rousseau, a Marx or an Einstein before their theories (especially political ones) can be tested in real life situations. This is exemplified here by Paulin Hountondji's statement on African philosophies. For him, "what a mockery it is to present such ambitious philosophies (as produced by Plato, Spinoza, and Hegel) and their scholarly survey of the history of philosophy... with what anthropologists are today presenting as 'African systems of thought' "(Owomoyela:179). This kind of comparative analysis is dangerous because it is not the level of technicality and sophistication that makes a philosophy relevant. Again, we forget that these Western philosophies were tested on the ground and this made them popular today. 
Finally, there is no direct relationship between democracy and development. The Asian Tigers, (South Korea, Taiwa, Malaysia and Singapore), Japan, China, etc were not democratic states during the years of development. Development was achieved before democratization. Democracy without regard for moral standards and values cannot take Africa anywhere. But whether it is a democracy or an oligarchy, the central issue is good leadership, and as Gabriel O. Olusanya ("We Build in Vain") says:

\begin{abstract}
Democracy without good leadership cannot salvage Nigeria ... it is difficult to see the Nigerian Society as it is, throw up the kind of leadership vital for democracy to succeed; for democracy cannot work in the absence of the right moral climate and of a consensus as to what constitutes the common good.
\end{abstract}

This, is no way belittles the goals of democracy, which are universal; it only shows that there is something wrong with the en-masse aping of western liberal democracy as a sinequanon for development. Perhaps, it is time to seriously try the non-party consensual democracy. And what better way to end our discussion than to quote Momoh again as he ruminates on W.E. Abraham's Cultural Essentialism. For him:

...The problem facing African leaders, therefore, comes down to one of retention, modification, and rejection of, on the one hand, some items in traditional African Culture and, on the other hand, items in Western and Middle Eastern cultures. In this regard, African leaders have a clear choice before them... One 
prominent and enviable item introduced by alien cultures is the investment in human resources and formal education. African leaders should retain and modify this, such that it discourages the greed for money and encourages the traditional African spirit for a welfare type of society ("Crisis in African Culture", 15-16).

However, with the outright neglect of "investment in human resource", we are groping in darkness. How can our "human-resource" base be developed (man is the agent for who and by which development is engendered) when we would rather take the demands (for improvement) by Tanker Drivers more seriously than that of University teachers, who are saddled with the development (production) of the next crop of leaders? No wonder we are in total agreement with Jeremiah Chidozie Chukwuokolo who argues that the epistemic perception of a people (what they consider as Truth) has a direct bearing on what they will "know"; and consequently, this will "determine the rate and pattern of development in such a society"5. What, if one may ask, is the epistemic world-view of our leaders? What are the epistemological and ontological understandings that mould their thoughts and guide their actions? Is it not power, fame and money? If we remember the psychological effect of the "Ghana-Must-Go" syndrome in Nigeria and the exalted state of Ghana's national culture today, we immediately see how deliberate policy by leadership could move a society a thousand giant step, at once! Ghana has shown Africa that a leader, who wanted to go another term in office, can actually accept defeat, congratulate his conqueror, and coolly hand over political power to him! What effect that would have in the polity! What tension that would douse! 
But it would appear that there is a "second" Berlin Conference going on all over Africa. The economic destiny of Africa is being handed over to individually-owned multinational corporations (MNCs) under the names of "market liberalization", "privatization", and "investments". But if we ever achieve any economic development from such efforts (which we doubt), we would eventually dig our graves because, without the development of the human person, any development noticeable is a pseudo one. And once economy is under foreign stranglehold, political leaders simply turn to puppets. Our leaders, definitely, have a choice to make, and fast too!

\section{References}

Abraham, W. Emmanuel, "Crisis in African Culture", in, Kwasi

Wiredu and Kwame Gyekye (ed.) Person and Community: Ghanaian Philosophical Studies I Washington: The Council for Research in Values and Philosophy, 1992.

Achebe, Chinua The Trouble with Nigeria Enugu: Fourth Dimension Publishers Ltd., 1985.

Agbo, Joseph N. "Africa Within the Globe: Confronting the

Parameters of Cross-Cultural Philosophy", in, Journal of Cultural Studies, Vol. 5, No.2 (2003).

Aigbodioh, J. A. "The Mindset Factor in Economic

Development, in, Irele, Dipo and Ekanola, Adebola

(ed.) The Development Philosophy of Emmanuel

Onyekwere: Anyiam Osigwe-Anyaim: Economic

Existence, Awareness and Responsibility. Ibadan:

Hope Publications, 2010.

Andah, B.W. African Development in Cultural Perspective, an occasional publication of the Department of 
Archeology and Anthropology, University of Ibadan (1982).

Appiah, Anthony In My Father's House: Africa in the Philosophy of Culture Oxford: Oxford University Press, 1992.

Azikiwe, Nnamdi Ideology for Nigeria: Capitalism, Socialism or Welfarism Lagos: Macmillan Publishers Ltd., 1997.

Chukwuokolo, J.C, "A Critical Examination of The Impacts of TheMind-Based Theories for the Development of The Society", SWEM: Journal of Religion and Philosophy, Vol 2 No.1 (August, 2008)

Cua, A.S. "The Status of Principles in Confucian Ethics", in,

N.V Chavchavadze, Ghia Nodia, \& Paul Peachey, (eds.) National Identity as an Issue of Knowledge and Morality Washington: The Council for Research in Values and Philosophy, 1994.

Davidson, Basil Africa in History New York: Macmillan Publishers, 1975.

Davidson, Basil African Civilization Revisited New Jersey: African World Press Inc., 1991.

Ely, Chinoy Society: An Introduction to Sociology New York: Random House, 1967.

Ideyi, Nwabuiro "Leadership and Nigeria's Quest for Good Governance: A Critical Evaluation" Sophia, vol. 10, No. 1 (Sept. 2007).

Ito, Youichi "Cultural Identity: An East Asian Perspective", in, Hellmut Schutte (ed.), Strategic Issues in Information Technology: International Implications for Decision Markers England: Rergamon Infotech, 1988.

Kluckhohn, Clyde and William, Kelly "The Concept of Culture", The Science of Man in World Crisis New York: Colombia University Press, 1945. 
Mazrui, Ali "Political Nostalgia", in, Ibadan Journal of Humanistic Studies, No. 2 (Oct. 1981).

Mill, J.S. On Liberty London: Oxford University Press, 1912.

Momoh, C.S. Philosophy of a New Past and an Old Future Auchi: African Philosophy Projects Publications. 1991.

Momoh, C.S. "On Cultural Philosophy," in Journal of African Philisophy and studies, Vol.1, 1 - 2 (1988).

Nwala, T.U. Igbo Philosophy Lagos: Literamed Publications Ltd., 1985.

Oguejiofor, Obi J. "is The African Worldview Responsible for The African Predicament?", Uche Vol.15 (2009)

Oguejiofor, Obi J. Philosophy and The African Predicament. Ibadan: Hope Publications, 2001

Ogundowole, E.K. "Self-reliancism: An Ideology in the making", WORLD FUTURES, Vol. 20 (1995) and later, Self-reliancism: Philosophy of a New Order Ikeja: John West Pub. Ltd. 1988.

Oladipo, Olusegun "Contemporary African Philosophy: Issues, Tasks, and Problems", A Paper Presented at the International Conference on African Philosophy at the SS Peter and Paul Major Seminary, Ibadan, March 27-31, 1995.

Olusanya, Gabriel Lecture Titled, "We Build in Vain", delivered at the 1996 Obafemi Awolowo Foundation Lecture on March 6, 1996; Published In WEEKEND CONCORD, March 9, 1996.

Oluwole, S.B. "The Africanness of a Philosophy", in her edited work, Readings in African Philosophy Lagos: Maastech Publishers, 1988.

Omoregbe, J.I. Knowing Philosophy Lagos: Joja Educational Research and Publishers Ltd., 1990.

Owomoyela, Oyeka "Africa and the Imperative of Philosophy: A Skeptical Consideration”, in, Tsenay 
Serequeberhan (ed.), African Philosophy: The Essential Readings New York: Paragon House, 1991. Reagan, Ronald in an address before the $39^{\text {th }}$ session of the U.N. General Assembly, New York, September $24^{\text {th }}$, 1984. Published in, Realism, Strength and Dialogue, A Compilation of the USIA, 1985.

Rodney, Walter How Europe Underdeveloped Africa, with introduction by Vincent Harding. Abuja: Panaf Publishers, 2009.

Schweitzer, A. Civilization and Ethics London: Unwin Books, 1961.

Wiredu, Kwasi Philosophy and an African Culture, London: Cambridge University Press, 1980.

Wiredu, Kwasi "Problems in Africa's Self-Definition in the Contemporary World", in, Wiredu/Gyekye (ed).

Joseph Agbo is of the Department of Philosophy and Religion, Ebonyi State University, Abakaliki 